\title{
Blended Learning in Law School at Northern Technical University in Ibarra, Imbabura, Ecuador
}

\author{
Harry Clavijo Suntura*, Omar Abreu Valdivia, Maribel Rosero Rosero, Gloria Aragón Cuamacás
}

Faculty of Administrative and Economic Sciences, North Technical University, July 17 Avenue. Postal Code 100105 Ibarra, Ecuador

Received April 29, 2020; Revised December 7, 2020; Accepted January 25, 2021

\section{Cite This Paper in the following Citation Styles}

(a): [1] Harry Clavijo Suntura, Omar Abreu Valdivia, Maribel Rosero Rosero, Gloria Aragón Cuamacás , "Blended Learning in Law School at Northern Technical University in Ibarra, Imbabura, Ecuador," Universal Journal of Educational Research, Vol. 9, No. 4, pp. 792- 798, 2021. DOI: 10.13189/ujer.2021.090411.

(b): Harry Clavijo Suntura, Omar Abreu Valdivia, Maribel Rosero Rosero, Gloria Aragón Cuamacás (2021). Blended Learning in Law School at Northern Technical University in Ibarra, Imbabura, Ecuador. Universal Journal of Educational Research, 9(4), 792 - 798. DOI: 10.13189/ujer.2021.090411.

Copyright $\odot 2021$ by authors, all rights reserved. Authors agree that this article remains permanently open access under the terms of the Creative Commons Attribution License 4.0 International License

\begin{abstract}
This article presents the results of a qualitative research, with analytical and interpretive case study methodology, about the impact of the opening of the Law career at the Technical University of the North (UTN) through the blended modality, its consequences from the negative and positive point of view for students, teachers and residents of the community. The aim of the work is to explain the results of the opening of the Law degree at UTN through the blended modality. In the research process, methods, techniques and instruments such as the survey, analysis, synthesis, documentary review and hermeneutics were applied, each with a specific purpose, explained the methodology section. The work includes the challenges that students and teachers have faced for the successful development of the career, in the knowledge of the content of the subjects, the pedagogy, the didactics, the methodology and the technological resources that the teaching-learning process of the subjects contemplated in the study plan. In the text that is submitted to the criteria of the academic community, a comparison of the efficiency indicators of this career is made with the other careers of the Faculty of Administrative and Economic Sciences (FACAE) of the UTN, whose results show that this was a decision necessary and wise.
\end{abstract}

Keywords Law, Blended Learning, Opportunities, Challenges

\section{Introduction}

In response to society's expectations, the university has undergone changes driven by efforts to improve the quality of education [5]. Education is a complex process and concerns about infrastructure and access are part of it [16].

As a result, Northern Technical University (UTN), a university based in Ibarra, Imbabura, Ecuador offers the possibility to study law through a blended learning program since 2015, at the Faculty of Administrative and Economic Sciences (FACAE). This option allows students previously enrolled in universities which have lost the status of higher education institutions to be able to attend law courses. Therefore, this contingency plan offers students a chance to continue their studies on weekends. This program is also an opportunity for students with limited resources and/or professionals to keep studying while working.

For these reasons, blended learning has gained popularity among the Ecuadorian society. UTN's blended learning law students come from different provinces of Ecuador. It shows that this way of studying is popular among Ecuadorians. It's a way to guarantee social inclusion in accordance with the 2008 Constitution of the Republic of Ecuador (article 26) which describes education as one of its priority.

"Education is a right of people throughout their lives and an absolute and inalienable duty of the State. It constitutes a priority for public policy and State investment, a guarantee of equality and social inclusion, and an essential condition for good living. 
Individuals, families and society have the right and responsibility to participate in the educational process" [25].

This work aims to explain the outcomes of blended learning in Law school at UTN

\subsection{Law Studies in Ecuadorian Universities: Current Situation}

Law as a scientific discipline and as a career has been at the core of social and political power in Western society [8]. It has been traditionally taught in a face-to-face environment, but this way of teaching is now challenged by our modern world[30].

The success of any given type of study depends on teachers' skills and requires students to be engaged in university studies [14]. Teachers' training (both academic studies and experience) and students' background affect the course outcomes just like the educational infrastructure do [28].

Through its blended teaching program, UTN has taken on an ambitious challenge. As a result, admission to the degree is very diverse. For instances, it is made up of high school graduates, but also students who have chosen to pursue a second degree, and those who are resuming their studies. This diversity makes the training process particularly complex and it requires qualified teachers.

This teaching approach implies a deep change of mindset for both teachers and students. This hybrid education model [15] requires moving away from a dogmatic vision of law studies often shared by both teachers and students [9].

The Regulations about the Academic Regime of the Council of Higher Education (CES) of Ecuador (2015) establish five ways of studies for degrees and programs. Those include Face-to-face course, blended course, dual course (not applicable to the law degree), online and distance learning.

Blended learning is very specific. It combines face-to-face and virtual activities. Institutions need high technology for students to develop specific skills such as IT, virtual communication, self-learning, self-discipline, cognitive independence among others. Self directed learning and both planned and synchronized tutorial supervision are two core components of blended teaching. They require strong content preparation from teachers who also have to adjust the way they organize their teaching method. Thus, as part of their professional duties, teachers have obviously to master the theory of law but also pedagogy, didactics, methodology, IT and communications technology.

Private universities in Ecuador offer more programs of study than public ones. Regarding Law school, they usually offer the 4 ways of study proposed by the (CES) for this degree. So far, private universities are the one who receive most law students. Institutions such as Universidad Regional Autónoma de los Andes (UNIANDES), Metropolitan University, Tecnológica Indoamericana, Universidad Católica del Ecuador and Universidad Católica de Cuenca register more than $90 \%$ of the country's admission in law courses. UNIANDES offers 2 types of study in its Law school, i.e. face-to-face and blended learning in 7 provinces out 24, Los Ríos, Imbabura, Carchi, Tungurahua, Santo Domingo, Chimborazo and Pastaza [23].

UTN is the only public institution offering this type of course for Law studies. This answers the current society demand.

\subsection{Strengths of the Law School Blended Course}

Lectures predominate and innovative pedagogical strategies are often deficient, therefore the opportunities for students to argue their ideas and develop critical and reflective thinking are limited [6].Lectures create an unbalanced teacher-student's relationship [9]. This approach is a limiting factor that prevents developing customized learning as students are introduced to the concepts related to the different branches of Law.

The challenge for universities is to overcome this orthodox view of Law and to imagine another way of teaching. This model should encourage critical thinking and reflection should prevail. Its goal should be the training of students who relate to their field as authors instead of actors [10].

Table 1. Law course offer (Face-to-face course, blended course, online and distance learning) according to SENESCYT

\begin{tabular}{ccccccc}
\hline Way of study & $\begin{array}{c}\text { Private } \\
\text { universities }\end{array}$ & $\begin{array}{c}\text { Percentage } \\
\text { column }\end{array}$ & $\begin{array}{c}\text { Percentage } \\
\text { row }\end{array}$ & $\begin{array}{c}\text { Public } \\
\text { universities }\end{array}$ & $\begin{array}{c}\text { Percentage } \\
\text { column }\end{array}$ & $\begin{array}{c}\text { Percentage } \\
\text { row }\end{array}$ \\
\hline Face-to-face & 11 & $65 \%$ & $55 \%$ & 9 & $90 \%$ & $45 \%$ \\
\hline Blended course & 0 & $0 \%$ & $0 \%$ & 1 & $10 \%$ & $100 \%$ \\
\hline Face-to-face and blended course & 3 & $18 \%$ & $100 \%$ & 0 & $0 \%$ & $0 \%$ \\
\hline $\begin{array}{c}\text { Face-to-face and online } \\
\text { Face-to-face, blended course and } \\
\text { online }\end{array}$ & 1 & $6 \%$ & $100 \%$ & 0 & $0 \%$ & $0 \%$ \\
\hline distance & 1 & $6 \%$ & $100 \%$ & 0 & $0 \%$ & $0 \%$ \\
\hline Total & 17 & $6 \%$ & $100 \%$ & 0 & $0 \%$ & $0 \%$ \\
\hline
\end{tabular}

Source: SENESCYT (2019) 
This new vision of law studies should involve students in the resolution of practical legal cases during their university education. It also requires the development of research studies, and it should foster the rigorous study and writing of academic papers. This vision means a shift in the way teachers teach. Relations between teachers and students should be dynamic and it should welcome students' feedback [21].

Blended learning requires independence. Thus, they should learn how to manage themselves their studies in a responsible way. Virtual activities and tasks should be encouraged to solve practical cases talked about during face-to-face classes.

This type of studies particularly benefits students with limited economic resources [13]. Indeed, they do not have to attend class daily, but only at weekends. Those who do not live in or near Ibarra, where UTN facilities lie, do not have to move in town. Such considerations allow many of them to reduce personal expenses.

Implementing remote studying is now possible thanks to the Internet. It breaks learning limitations, it broadens students' horizons and it complements traditional teaching methods [19].Therefore, because of digital technology, educational institutions face the challenge of implementing new way of teaching in order to train new generations of students [12].

UTN rose to the challenge and added blended law courses to its academic offer. The institution's IT resources allow teachers to plan curriculum contents and develop activities in virtual classrooms. Teachers and students keeps in touch through the university's virtual platform. In addition, students can access the virtual library nationwide.

IT resources and trained teaching staff are both crucial elements to the successful implementation of the blended learning approach in the law school. This requires adjustment and time [22]. It is important that both students and teachers receive information and training about the benefits of the correct use of technology and the development of activities such as autonomous and team work, independent tasks, debates, dialogues, exchange of ideas, practical classes, seminars, workshops, symposiums, round tables, among others [1]. The idea is to develop an integrative, dynamic, flexible, rigorous, coherent, and innovative teaching and learning process [2].

Within this framework, it is advisable to invest in teacher training [11]. Since the current generation of students has grown up in the digital era, absorbing more technology is only a click away for them [27]. On the contrary, for teachers it is another story. For them, it is a major shift from traditional to modern technology.

\section{Methodology}

This research paper is a qualitative work. Its methodology is based on an analytical and interpretative case study. To collect information among UTN law students, a survey was prepared using Google form online platform. According to data published on UTN's web page, 539 law students enrolled in various programs for the March-August 2019 academic semester period. More than $50 \%$ of these students are between first and fourth grade. For this reason, this specific group of students was considered as informants in order to learn about their motivations, skills and difficulties in this field of study.

A documentary review served to provide information related to law programs in Ecuador but also to review publications in databases such as Scopus, Latindex and Mendeley regarding blended learning in other universities around the world. Gathered information was also analyzed and synthesized and a report was written.

\section{Sample of blended learning law students}

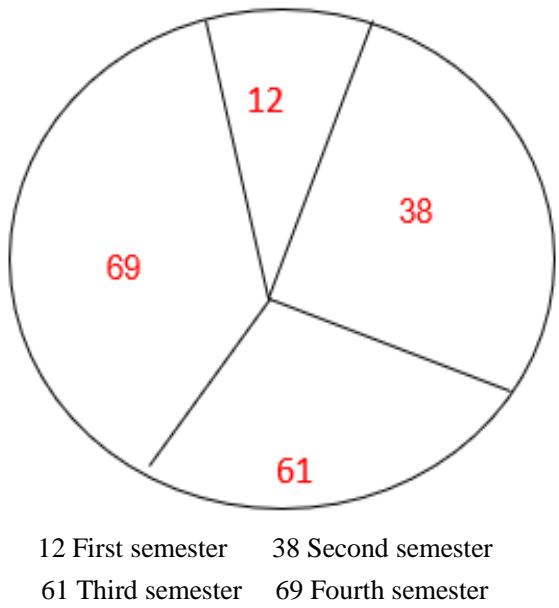

Figure 1. Sample used to establish skills of law students enrolled in blended learning

\section{Results}

After having completed their high school education in Ecuador, students need to choose a study program that will define their professional career but also their personal life. This decision is based on a number of criteria such as family income, university prestige, employability, degree of commitment and perseverance, among the most influential factors.

Figures published by the Ministry of Higher Education, Science, Technology and Innovation (SENESCYT) in 2019, show that the law program ranks fourth among the 16 most applied courses in the country. In total, there are 8586 students enrolled in the program nationwide. Only Medicine, Nursing and Administration exceed that number. UTN university is the only public institution offering this course in the country's northern part (i.e. zone 1) and it covers about $6 \%$ of the national demand [23].

The results of the research showed that work does not overwhelmingly influence the choice of blended law studies. Indeed, among 180 participants in the sample, only $45 \%$ worked. Other reasons mentioned are: 
Easiness of access (33\%), flexitime (23\%), university prestige (15\%), costs (13\%) and other reasons (18\%).

Blended learning means that teachers have to orient training in the classroom in a different way. It requires the use of teaching strategies that favour student's performance in the teaching-learning process [26].

The results of the surveys conducted among UTN's Law degree students showed that the top skill they look for in their education are: understanding and interpreting texts and other educational resources, and resolving legal problems. In this sense, their class should guide students to have the tools to solve problems, communicate, collaborate, experiment, think critically, and express themselves creatively [17].

Most sources of study of the Law degree micro-curriculum are manuals and laws. However, based on Figure 2, it can be inferred that blended learning presents difficulties in understanding and interpreting texts. In this regard and according to data published by the National Institute of Statistics and Censuses (INEC) in 2012, 27\% of Ecuadorians do not read much. 83\% of those who are accustomed to reading are young people between 16 and 24. 33\% of them read because of academic obligations and $32 \%$ because they know something about the field. $56.8 \%$ of respondents do not read because of lack of interest, time, and concentration. 50.3\% of those who read do so 1 hour per week and $13.5 \%$ from 3 to 4 hours. $31 \%$ read only newspapers and $28 \%$ books. $54 \%$ do so at home and only $0.3 \%$ in libraries. No age group reads just for pleasure or self-improvement [24].

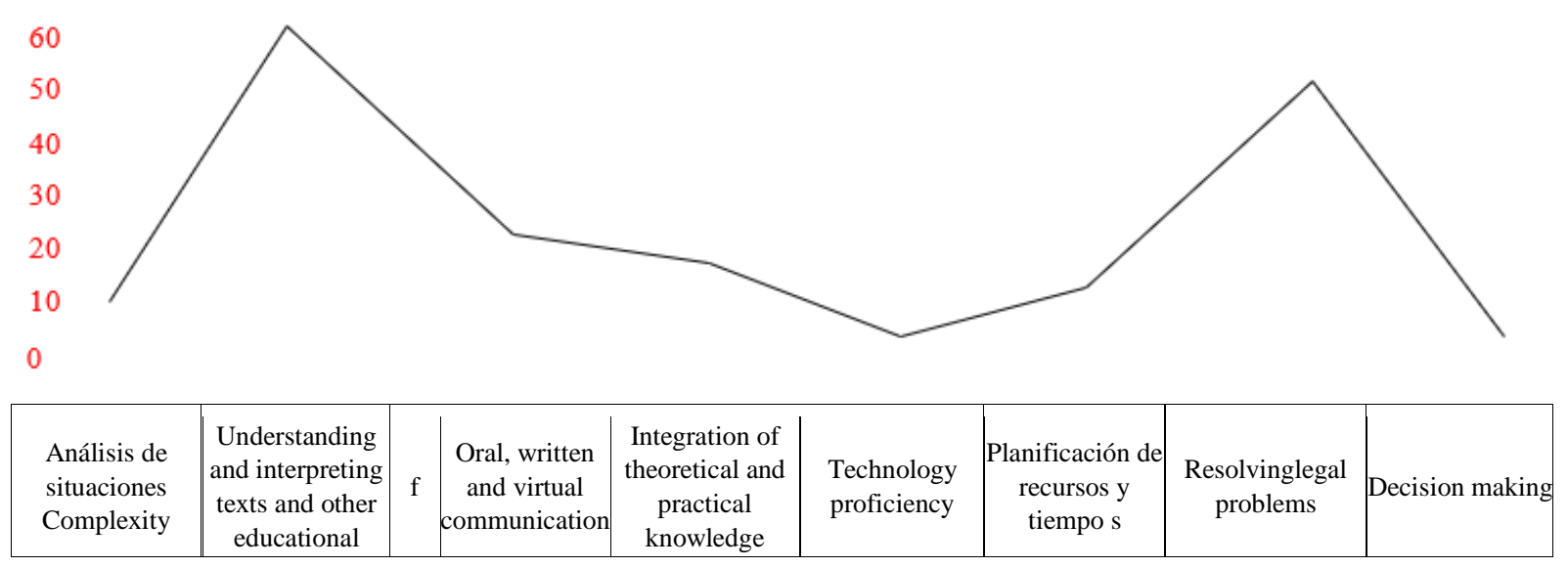

Figure 2. Competences to be developed in the blended modality of the UTN Law career

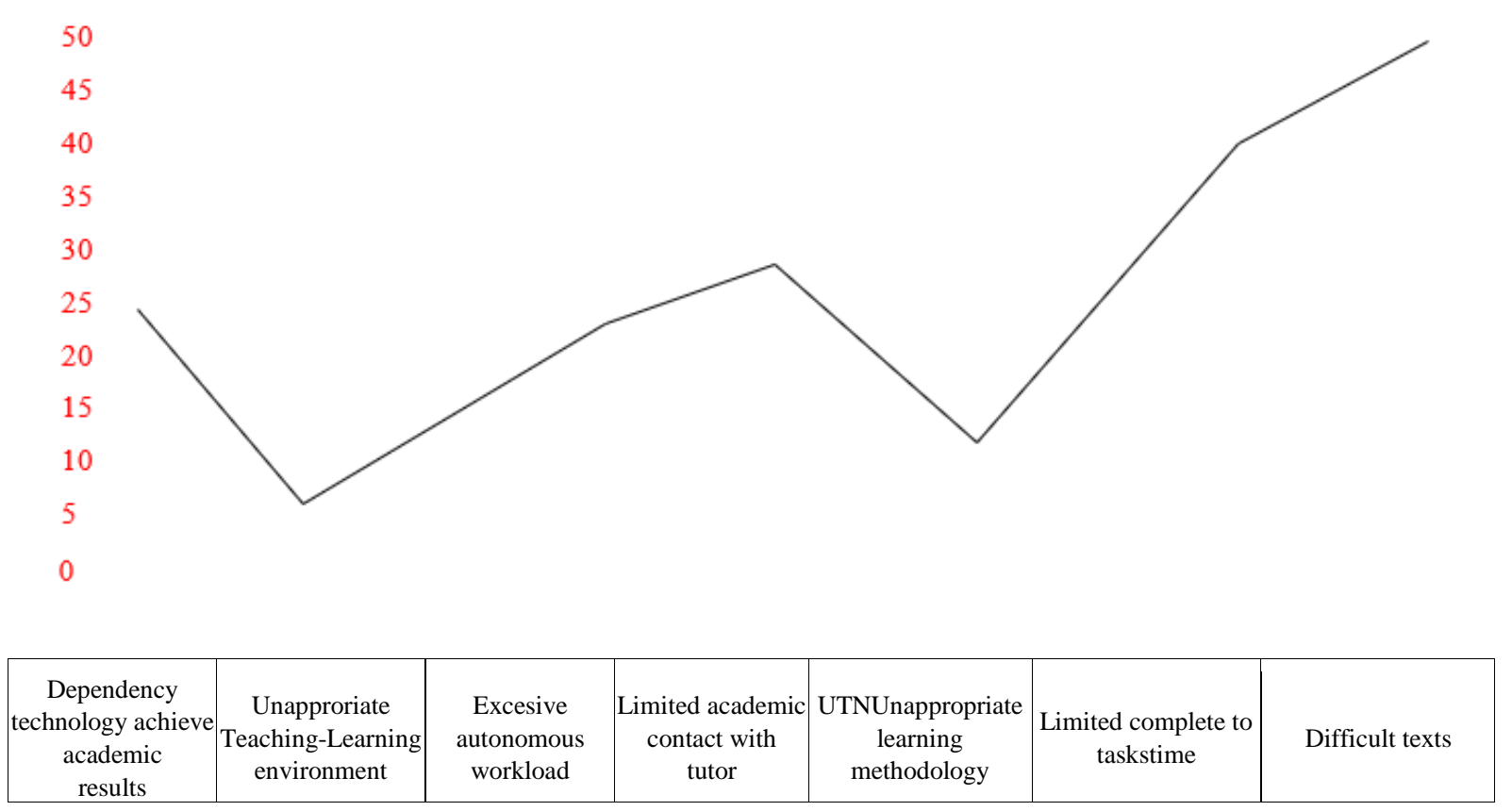

Figure 3. Priorities for teacher care 
Face-to-face learning is limited to weekends so it has a negative impact on the learning process as direct meeting with teachers and tutoring only takes place 2 days a week. It is important to recall that approximately $45 \%$ of students work from Monday to Friday. This can impact both performance and the teaching-learning environment. It means that teachers have to use different methodology based on efficient planning and higher virtual interaction with student's.

Students starting the course have highlighted 7 key difficulties they experienced. Those are illustrated in Figure 3. They are considered to be priorities for teachers' attention.

The law school was created in 2015. It is the last degree opened at UTN s FACAE. However, with $20.3 \%$ of the faculty's students, it counts with the highest number of students enrolled along with accounting and auditing. Such data shows that the blended learning is well received in both degrees, as shown in table 2 .

Table 2. FACAE programs admissions October 2019-February 2020

\begin{tabular}{ccccc}
\hline Nb. & Degree & Way of study & Admission & Total \\
\hline 1 & Management & Face-to-face & 311 & 3111 \\
2 & $\begin{array}{c}\text { Accounting and } \\
\text { auditing CPA }\end{array}$ & Face-to-face & 515 & \\
& $\begin{array}{c}\text { Accounting and } \\
\text { auditing CPA }\end{array}$ & $\begin{array}{c}\text { Blended } \\
\text { learning }\end{array}$ & 385 & 900 \\
& $\begin{array}{c}\text { Economy specialty } \\
\text { in Finance }\end{array}$ & Face-to-face & 380 & 380 \\
4 & Marketing & Face-to-face & 280 & 280 \\
5 & Turism & Face-to-face & 239 & 239 \\
6 & Gastronomy & Face-to-face & 177 & 177 \\
7 & Law & Blended & 585 & 585 \\
& learning & 2872 & 2872 \\
\hline
\end{tabular}

Mixed learning develops important aspects in student's such as: Developing a dynamic attitude towards study, work, family and social life, responsibility, autonomy, discipline, academic creativity, resources management related to the teaching-learning process, systematic feedback, daily life management, management of time and resources, developing skills and abilities

For teachers, blended learning brings its own constraints. This way of teaching requires changing the way teachers work. This calls for skilled professionals. Such teachers must regularly update their knowledge, master their subjects, explore new ways of engaging with students, use their pedagogical, didactic, methodological, communicative, organizational and IT skills, while being demanding, flexible and dynamic with students. In other words, those educators must have overcome the traditional teaching-learning model. They embrace alternative teaching methods that promote gradual learning. They also have diverse models of reference. In short, it requires sophisticated approaches to understanding the world and acting on it [3].
As face-to-face classes are taught at weekends, some teachers are practicing professionals from legal institutions. This allows students to receive updated practical knowledge during their training process. Nevertheless, teaching under the new conditions set by blended learning is also a major challenge for teachers. Indeed, they have to handle two activities and follow a process of continuous training. It must also be considered that more than $85 \%$ of the law school teaching body has not received any pedagogical training. To address this problem, FACAE has developed 4 research projects including training related to blended learning.

These projects are called "FACAE integrative didactic model for 2016-2017", "Resizing teachers' research skills at FACAE for 2017-2018", "Enhancing teachers' skills for the design of the teaching-learning process in the accounting and auditing course for 2017-2018" and "content, methods, evaluation, and learning development teachers training system at FACAE in 2019".

The October-December 2019 teachers training included courses on legal epistemology, administrative law and the organic code of administration, the organic code of criminal law and the pedagogy of law. These points have successfully prepared professors to face the challenges of the blended learning course. As shown in table 3, among eight courses offered by FACAE, the program ranks fourth in terms of grade repetition and second in terms of drop out rate.

Table 3. Grade repetition and university drop out rates at FACAE October2019-February2020

\begin{tabular}{|c|c|c|c|c|c|}
\hline Nb. & Degree & Way of study & $\begin{array}{c}\text { Nb of } \\
\text { students }\end{array}$ & $\begin{array}{c}\text { Repetiti } \\
\text { Drop out } \\
\text { on }\end{array}$ & \\
\hline 1 & Management & Face-to-face & 311 & $6 \%$ & $3 \%$ \\
\hline \multirow[t]{2}{*}{2} & $\begin{array}{l}\text { Accounting and } \\
\text { auditing CPA }\end{array}$ & Face-to-face & 515 & $8 \%$ & $3 \%$ \\
\hline & $\begin{array}{l}\text { Accounting and } \\
\text { auditing CPA }\end{array}$ & $\begin{array}{l}\text { Blended } \\
\text { learning }\end{array}$ & 385 & $10 \%$ & $4 \%$ \\
\hline 3 & $\begin{array}{c}\text { Economy specialty } \\
\text { Finance }\end{array}$ & Face-to-face & 380 & $11 \%$ & $4 \%$ \\
\hline 4 & Marketing & Face-to-face & 280 & $4 \%$ & $3 \%$ \\
\hline 5 & Turism & Face-to-face & 239 & $3 \%$ & $2 \%$ \\
\hline 6 & Gastronomy & Face-to-face & 177 & $10 \%$ & $3 \%$ \\
\hline \multirow[t]{3}{*}{7} & Law & $\begin{array}{l}\text { Blended } \\
\text { learning }\end{array}$ & 585 & $7 \%$ & $3 \%$ \\
\hline & \multirow{2}{*}{$\begin{array}{l}\text { Total } \\
\text { Average }\end{array}$} & & 2872 & $59 \%$ & $25 \%$ \\
\hline & & & & $7 \%$ & $3 \%$ \\
\hline
\end{tabular}

\section{Discussion}

That the Bologna Declaration (1999) and its implementation through the European Higher Education Area (EHEA), marked a turning point and a change of paradigm in university education in Ecuador. At the same time, the increasing use of IT in the teaching/learning 
process at the university has brought about new methodologies involving face-to-face learning but also blended learning and virtual activities [20].

For [4] the most valued assets of face-to-face education is to be able to apply learning, as well as face-to-face interaction which is important for motivating participants and creating bonds, and finally the possibility of carrying out more demanding activities than those that can be undertaken otherwise.

According to [29]the number of degrees and training courses offering this type of study has significantly increased and it has become an option seriously considered by a growing number of institutions, especially universities. This has led to substantial increases of students choosing this type of education.

According to [18] this way of study prevents space and time barriers, employment or student level from affecting the teaching-learning process. Learning is a dialogical process. With distance education, it is developed with pedagogical mediation, which is provided by the teacher who uses technological tools to teach.

About the challenges of blended learning, [7] thinks that pedagogues should leave behind longstanding disputes between traditionalists and specialists. Instead, focus should be on interdisciplinary work and efforts should be oriented towards achieving a true pedagogical revolution enhancing essential interactions in the process of teaching and learning. Both teachers and student's roles have to radically change.

All of these elements show that blended learning has gained strength and space in higher education, and that it is increasingly relevant in the current way of life. This sensible and practical option benefits the people who need it. At the same time, it represents a challenge that requires constant training from managers, teachers and students to adjust to the new realities.

\section{Conclusions}

Blended learning at UTN law school promotes inclusion into the university system. Without this option, various social groups could not have access to higher education institutions because of employment or financial reasons.

Blended learning of law and the use of IT resources redefine the traditional teacher-student asymmetric relationship because teaching is now based on case studies. The teacher becomes an intermediary in the training of the student's.

Blended learning also makes it possible for professionals experienced in the practice of law to join the teaching body. Admission figures show that blended learning is highly attractive among students, and low rates of repeating classes and drop-out are valuable indicators of its efficiency.

\section{REFERENCES}

[1] Abreu, O., Rhea, S., Arciniegas, G., S. Guevara, "Competencia para el diseño y la ejecución del proceso de enseñanza-aprendizaje en la Facultad de Ciencias Administrativas y Económicas, Universidad Técnica del Norte de Ecuador”, Formación universitaria, vol. 13, no. 4, págs. 153-164, 2020, http://dx.doi.org/10.4067/S0718-5006 2020000400153

[2] Abreu, O., Rhea, S., Arciniegas, G., M. Rosero, “Objeto de Estudio de la Didáctica: Análisis Histórico Epistemológico y Crítico del Concepto”, Formación universitaria, vol. 11, no. 6, págs. 75-82, 2018. http://dx.doi.org/10.4067/S0718-500 62018000600075

[3] Abreu, O., Naranjo, M., Rhea, B., M. Gallegos, "Modelo Didáctico para la Facultad de Ciencias Administrativas y Económicas de la Universidad Técnica del Norte en Ecuador”, Formación universitaria, vol. 9, no. 4, págs. 03-10, 2016, http://dx.doi.org/10.4067/S0718-5006 2016000400002.

[4] Amato, D., X. Novales-Castro, "Utilidad para el aprendizaje de una modalidad educativa semipresencial en la carrera de Medicina”, Investigación en educación médica, vol. 3, no.11, págs. 147-154, 2014, https://doi.org/10.1016/S2007-5057(14)72741-3

[5] Bas, C., Tarantola, S., Carot, J., A. Conchado, "Sensitivity Analysis: A Necessary Ingredient for Measuring the Quality of a Teaching Activity Index”, Soc Indic Res, vol. 131, págs. 931-946, 2017, DOI: 10.1007 / s11205-016-1297-2

[6] Bayuelo, A "La educación y el Derecho en torno a un nuevo paradigma transformador” Revista Justicia, vol. 27, págs. 167-184, 2015, http://dx.doi.org/10.17081/just.3.27.326.

[7] Begoña, M. "Educación y nuevas tecnologías. Educación a Distancia y Educación Virtual” Revista de Teoría y Didáctica de las Ciencias Sociales, no. 9, págs. 209-222, 2004, https://www.redalyc.org/pdf/652/65200912. pdf

[8] Bühlmann, F., Benz, P., Mach, A., T. Rossier, “Mapping the Power of Law Professors: The Role of Scientific and Social Capital. Minerva, no. 55, págs. 509-531, 2017, https://doi.org/10.1007/s11024-0179333-1

[9] Coloma, R. "El ocaso del profesor Binns: Un ensayo acerca de la enseñanza del derecho en Chile” Ius et Praxis, vol. 11, no. 1, págs. 133-172, 2005, https://doi.org/10.4067/S071800122005000100006

[10] Corona, L., J. Arredondo, “Ciencia jurídica y ensenanza del Derecho. Primeros pasos hacia una concepción del Derecho, Revista de Derecho y Ciencias Sociales,vol. no. 8, págs. 55-73, 2015, file:///C:/Users/HP/Downloads/Dialnet-Cienci aJuridicaYEnsenanzaDelDerecho-5645597.pdf

[11] Díaz, E. “La formación del profesional en la Educación Superior en la carrera de Derecho en Ecuador.Espacios, vol. 39, no. 29, págs. 1-11, 2018, https://www.revistaespacios.c om/a18v39n29/a18v39n29p01.pdf

[12] Drossel, K., B. Eickelmann, “Teachers' participation in professional development concerning the implementation of new technologies in class: a latent class analysis of teachers and the relationship with the use of computers, ICT 
self-efficacy and emphasis on teaching ICT skills" Large-Scale Assessments in Education, vol 5, no. 19, 2017, https://doi.org/10.1186/s40536-017-0053-7

[13] Dziuban, C., Graham, C. R., Moskal, P. D., Norberg, A., N. Sicilia, „Blended learning: the new normal and emerging technologies”, International Journal of Educational Technology in Higher Education, vol. 15, no. 1, págs. 1-16, 2018, https://doi.org/10.1186/s41239-017-0087-5

[14] Ferrante, F. “Assessing Quality in Higher Education: Some Caveats”, Soc Indic Res, no. 131, págs. 727-743, 2017, https://doi.org/10.1007/s11205-016-1267-8

[15] Galvis, Á. H. "Supporting decision-making processes on blended learning in higher education: literature and good practices review”, International Journal of Educational Technology in Higher Education, vol. 15, no. 1, págs. 1-38, 2018, https://doi.org/10.1186/s41239-018-0106-1

[16] Hanushek, E. "Economic growth in developing countries: The role of human capital”, Economics of Education Review, vol. 37, págs. 204-212, 2013, https://doi.org/10.1016/j.econ edurev.2013.04.005

[17] Imbernón, F., Silva, P., C. Guzman, “Competencias en los procesos de enseñanza - aprendizaje virtual y semipresencial, Revista Cientifica de Educomunicación, vol. XVIII. no. 36, págs. 107-114, 2011, DOI:10.3916/C36-201 1-03-01

[18] Martínez, C. H. “La educación a distancia: sus características y necesidad en la educación actual.Educación, vol. XVII, no. 33, págs. 7-27, 2008, https://dialnet.unirioja.es/servlet/articulo?codigo=5057022

[19] Lee, L. T., J.C. Hung, „Effects of blended e-Learning: a case study in higher education tax learning setting”, Human-Centric Computing and Information Sciences, vol. 5, no. 1, (2015, https://doi.org/10.1186/s13673-015-0024-3

[20] Pallisé, J.S., Benedí, C., Blanché, C., M. Bosch, ”La semipresencialidad en Educación Superior: casos de estudio en los grados de la Universidad de Barcelona. EDUTEC, Revista Electrónica de Tecnología Educativa, no. 58, págs. 15-33, 2016, https://doi.org/10.21556/edutec.2016.58.697

[21] Pérez, L. "El sistema de ensenanza del Derecho y acceso a las profesiones jurídicas en Alemania: Lecciones para el debate en México”, Boletín Mexicano de Derecho
Comparado, vol. L, no. 151, págs, 263-311, 2018, https://doi.org/10.22201/iij.24484873e.2018.151.12295

[22] Protsiv, M., Rosales-Klintz, S., Bwanga, F., Zwarenstein, M., S. Atkins, „Blended learning across universities in a South-North-South collaboration: A case study", Health Research Policy and Systems, vol. 14, no. 1, págs. 1-12, 2016, https://doi.org/10.1186/s12961-016-0136-x

[23] República del Ecuador. Secretaría de Educación Superior, Ciencia, Tecnología e Innovación.:. Oferta académica de las instituciones de educación superior, 2019, http://admision.senescyt.gob.ec/media/2019/07/Oferta-2doSemestre-2019_Digital_.pdf.

[24] República del Ecuador. Instituto Nacional de Estadísticas y Censos, "Hábitos de lectura en Ecuador,2012, http://www.celibro.org.ec/web/img/cms/ESTUDIO\%20HA BITOS\%20DE\%20LECTURA\%20INEC.pdf

[25] República del Ecuador.: Constitución de la República del Ecuador. Disponible en: https://www.oas.org/juridico/pdfs/ mesicic4_ecu_const.pdf (2008).

[26] Ruiz, F. J., J.M. Rodas, "Factores motivacionales que orientan la decisión de ingresar a la licenciatura en biología y química de la universidad de caldas, manizales, Colombia, Revista Latinoamericana de Estudios Educativos, vol. 7, no. 2, págs. 11-35,2011,<http://www.redalyc.org/articulo.oa?id $=134125454003>$ ISSN 1900-9895 (2019).

[27] Sinclair, J., S. Kalvala, "Engagement measures in massive open online courses", Communications in Computer and Information Science, vol. 533, págs,. 3-15, 2015, https://doi.org/10.1007/978-3-31922629-3_1

[28] Solari, E. "El currículo chileno de estudios jurídicos", Revista de Derecho de La Pontificia Universidad Católica de Valparaíso, Chile, vol. XXXIX, no.39, págs. 703-734, 2012, http://dx.doi.org/10.4067/S0718-68512012000200024

[29] Suárez, J. M., D. Anaya, "Educación a distancia y presencial: diferencias en los componentes cognitivo y motivacional de estudiantes universitarios”, RIED. Revista Iberoamericana de Educación a Distancia, vol. 7, no.1-2, págs. 65-75,2012, https://doi.org/10.5944/ried.7.1-2.1075

[30] Wilkesmann, U., Lauer, "What affects the teaching style of German professors? Evidence from two nationwide survey", ZeitschriftFürErziehungswissenschaft, vol. 18, no. 4, págs. 713-736, 2015, https://doi.org/10.1007/s11618-015-0628-4 